Research Paper

\title{
The use of singleplex and nested PCR to detect Batrachochytrium dendrobatidis in free-living frogs
}

\author{
Selene Dall'Acqua Coutinho ${ }^{1}$, Julieta Catarina Burke ${ }^{1}$, Catia Dejuste de Paula ${ }^{2}$, \\ Miguel Trefaut Rodrigues ${ }^{3}$, José Luiz Catão-Dias ${ }^{2}$ \\ ${ }^{1}$ Laboratório de Biologia Molecular e Celular, Universidade Paulista, São Paulo, SP, Brazil. \\ ${ }^{2}$ Laboratório de Patologia Comparada de Animais Selvagens, Faculdade de Medicina Veterinária e \\ Zootecnia, Universidade de São Paulo, São Paulo, SP, Brazil. \\ ${ }^{3}$ Instituto de Biociências, Universidade de São Paulo, São Paulo, SP, Brazil.
}

Submitted: February 5, 2014; Approved: August 1, 2014.

\begin{abstract}
Many microorganisms are able to cause diseases in amphibians, and in the past few years one of the most reported has been Batrachochytrium dendrobatidis. This fungus was first reported in Brazil in 2005; following this, other reports were made in specimens deposited in museum collections, captive and free-living frogs. The aim of this study was to compare singleplex and nested-PCR techniques to detect $B$. dendrobatidis in free-living and apparently healthy adult frogs from the Brazilian Atlantic Forest. The sample collection area was a protected government park, with no general entrance permitted and no management of the animals there. Swabs were taken from the skin of 107 animals without macroscopic lesions and they were maintained in ethanol p.a. Fungal DNA was extracted and identification of $B$. dendrobatidis was performed using singleplex and nested-PCR techniques, employing specific primers sequences. B. dendrobatidis was detected in 61/107 (57\%) and 18/107 $(17 \%)$ animals, respectively by nested and singleplex-PCR. Nested-PCR was statistically more sensible than the conventional for the detection of $B$. dendrobatidis $($ Chi-square $=37.1 ; \alpha=1 \%$ ) and the agreement between both techniques was considered just fair $($ Kappa $=0.27)$. The high prevalence obtained confirms that these fungi occur in free-living frogs from the Brazilian Atlantic Forest with no macroscopic lesions, characterizing the state of asymptomatic carrier. We concluded that the nested-PCR technique, due to its ease of execution and reproducibility, can be recommended as one of the alternatives in epidemiological surveys to detect $B$. dendrobatidis in healthy free-living frog populations.
\end{abstract}

Key words: chytridiomycosis, Batrachochytrium dendrobatidis, frogs, Brazilian Atlantic Forest, PCR.

\section{Introduction}

Of the 6,200 species of living anurans (Frost, 2013), approximately $30 \%$ are endangered, presenting the greatest risk situation on the planet (IUCN-ASG, 2013). The decline and extinction of amphibians that have been detected over the last few decades has no precedent in the last millennia (Stuart et al., 2004).

Many microorganisms cause diseases in amphibians, and in the past few years, one of the most widely reported has been Batrachochytrium dendrobatidis, a Chytridiomycete fungus of the order Rhizophydiales (Longcore et al., 1999; de Hoog et al., 2004). Chytridiomycosis is a highly contagious disease that occurs worldwide and can lead to a fatal evolution (Fisher et al., 2009; James et al., 2009; Voyles et al., 2009), and chytridiomycosis has been added to the list of compulsory notifiable diseases by the World Organization for Animal Health (OIE, 2013). 
These fungi degrade cellulose and keratin, and the infectious form of $B$. dendrobatidis is the zoospore (Longcore et al., 1999; de Hoog et al., 2004).

Although there is no consensus on the infective dose for amphibians, the presence of only a single zoospore may be sufficient for the installation and multiplication of the fungus, and infections with a small inoculum (100 zoospores) can cause death in certain species of frogs (Berger et al., 1999; Daszak et al., 1999; James et al., 2009).

These fungi grow within and are able to damage keratinized cells. In histological sections, skin affected by the fungus shows a thickening of the stratum corneum and the presence of sporangia; the evolution of infection causes hyperkeratosis and alterations in the normal epidermis architecture (Longcore et al., 1999; Hyatt et al., 2007).

Due to the role of the skin in these animals, previous studies have suggested that infection with $B$. dendrobatidis may affect cutaneous osmoregulation because the changes introduced by the fungus inhibit sodium absorption, compromising the conduction of water and electrolytes and the functions of osmoregulation (Voyles et al., 2009).

This fungus was first described in 1999 (Longcore et $a l .$, 1999), and since then, conclusive evidence has suggested that $B$. dendrobatidis infection could be related to the decline of amphibian populations throughout the world (Daszak et al., 1999; James et al., 2009; Voyles et al., 2009). Factors related to human impacts, such as climate change, pollution, deforestation and expansion of crop lands, can together contribute to the transmission of the disease and occurrence of outbreaks (Daszak et al., 1999; Garner et al., 2006; Fisher et al., 2009; James et al., 2009).

The first report of chytridiomycosis in Brazil occurred in tadpoles of the Brazilian Atlantic Forest, which presented oral deformities (Carnaval et al., 2005; Toledo et al., 2006a). Later, chytridiomycosis was observed in specimens deposited in museum collections (Carnaval et al., 2006; Toledo et al., 2006b) and captive (de Paula et al., 2010) and free-living amphibians (Ramalho et al., 2013). $B$. dendrobatidis infection has also been reported in Brazilian farm bullfrogs (Schloegel et al., 2009) and species of frogs inhabiting different altitudes (Grundler et al., 2012). However, there is no record of natural outbreaks in freeliving anurans in Brazil (OIE, 2013).

Because Brazil hosts the highest diversity of amphibians in the world, with 946 species (Segalla et al., 2012), and the existence of the fungus in Brazil has been verified, epidemiological surveys in the wild are urgently needed to provide more information about the presence of $B$. dendrobatidis in different species and ecosystems (Grundler et al., 2012; Ramalho et al., 2013).

The most commonly used diagnostic tests for identifying $B$. dendrobatidis utilize histological methods and molecular biology, particularly singleplex, nested or real-time PCR (Berger et al., 1999; Annis et al., 2004; Retallick et al., 2006; Hyatt et al., 2007; Kirshtein et al., 2007). Molec- ular diagnostic techniques use specific primers to detect fungus, and recent publications have considered real-time and nested PCR more sensitive than singleplex (Boyle et al., 2004; Garner et al., 2006; Goldberg et al., 2007; Garland et al., 2011).

Therefore, this study aimed to compare the performance of singleplex and nested PCR in detecting $B$. dendrobatidis in free-living and apparently healthy adult frogs from the Brazilian Atlantic Forest along the São Paulo state coast.

\section{Materials and Methods}

Samples were collected at the Boracéia Biological Station $\left(23^{\circ} 39^{\prime} 14.10^{\prime \prime} \mathrm{S}, 45^{\circ} 53^{\prime} 22.53^{\prime \prime} \mathrm{W}\right)$, a protected area maintained in nearly pristine condition by the Museum of Zoology, University of São Paulo, São Paulo state, with no general entrance permitted for visitors. No animal management occurs at this site. Anurans were captured using non-powdered latex gloves and transported in individual plastic bags containing air to the laboratory, where they were physically restrained for sampling. Swabs were taken from the skin of 107 free-living adult frogs (13 genera and 28 species) showing no macroscopic lesions. Sterile swabs were rubbed over the entire body of the animals, preserved in ethanol p.a. and maintained refrigerated (Daszak et al., 1999). All necessary ethical and environmental permits and principles were observed.

The extraction of fungal rDNA was performed with the PureLink ${ }^{\mathrm{TM}}$ Genomic DNA Mini Kit (Invitrogen $^{\mathrm{TM}}$, Carlsbad, CA, USA) according to the manufacturer's guidelines. The identification of $B$. dendrobatidis was performed by singleplex (conventional) PCR, with a limit detection of approximately 10 fungus zoospores, using primers that amplify a specific sequence of rDNA of $B$. dendrobatidis: Bdla (5'CAGTGTGCCATATGTCACG3') and Bd2a (5'CATGGTTCATATCTGTCCAG3') (Annis et al., 1999). The reactions were performed in a volume of $25 \mu \mathrm{L}$ with $5 \mu \mathrm{L}$ of DNA (50 ng), $2.5 \mu \mathrm{L}$ of each primer $(1 \mu \mathrm{M}), 12.5 \mu \mathrm{L}(1 \mathrm{X})$ of Go Taq ${ }^{\circledR}$ Hot Start Green Master Mix (Promega, Madison, WI, USA) and $2.5 \mu \mathrm{L}$ of nuclease-free water according to the manufacturer's guidelines.

The amplification reactions were performed in an Eppendorf Mastercycler Gradient ${ }^{\circledR} 5333$ thermocycler (Eppendorf, Hamburg, Germany) and consisted of an initial denaturation at $93^{\circ} \mathrm{C}$ for $10 \mathrm{~min}$, followed by 30 cycles of $45 \mathrm{~s}$ at $93^{\circ} \mathrm{C}, 45 \mathrm{~s}$ at $60^{\circ} \mathrm{C}, 1 \mathrm{~min}$ at $72^{\circ} \mathrm{C}$ and a final extension for $10 \mathrm{~min}$ at $72{ }^{\circ} \mathrm{C}$. After amplification, the samples were submitted to electrophoresis on agarose gel (1\%), stained with ethidium bromide $(0.5 \mu \mathrm{g} / \mathrm{mL})$, visualized on a UV transilluminator and photographed using the Gel Logic 200 Kodak system (Eastman Kodak Co., Rochester, NY, USA). Nested PCR was performed by repeating all of the procedures described above in the products obtained by 
singleplex PCR. Positive $B$. dendrobatidis DNA obtained from the Amphibian Disease Laboratory of San Diego Zoo, California, USA, was used (Dr. Allan Pessier). The results of the two techniques employed were compared using Chisquare $(\alpha=1 \%)$ and concordance analysis ( $\kappa$ - Kappa) tests (Siegel and Castellan, 1988).

\section{Results}

We detected $B$. dendrobatidis in 28 different species of frogs. B. dendrobatidis was detected in 61/107 (57\%) and 18/107 (17\%) animals, respectively, by nested and singleplex PCR (Table 1 and Fig. 1). Nested PCR was more sensitive than singleplex PCR for detecting $B$. dendrobatidis in healthy frogs (Chi-square $=37.1 ; \alpha=1 \%$ ) and the agreement between both techniques was considered only fair (Kappa $=0.27)$.

The remaining 46 sampled animals tested negative for the presence of $B$. dendrobatidis.

\section{Discussion}

The detection of $B$. dendrobatidis in 28 different species of frogs is consistent with previous results that observed the fungus virtually worldwide, with disease occurrence in a broad range of hosts (Hyatt et al., 2007; Fisher et al., 2009; James et al., 2009; Grundler et al., 2012).

Other studies conducted in Brazil have observed the occurrence of the fungus in the Brazilian Atlantic Forest (Carnaval et al., 2006; Toledo et al., 2006b; Schloegel et al., 2009), as well as in animals from the Cerrado (Brazilian savannah) (Ramalho et al., 2013). Our study confirmed the high prevalence of the fungus in Brazil.

The analyzed animals were from the wild and had no macroscopic lesions or clinical signs of the disease; thus, they were characterized as asymptomatic carriers and could be sources of infection for other animals. Declines in amphibian populations in the Brazilian Atlantic Forest have been reported, and the affected sites include the present study area; however, the causes of these decreases have not yet been determined (Verdade et al., 2013). It would be interesting to expand epidemiological surveys on the presence of B. dendrobatidis to other Brazilian biomes to obtain more information on the distribution of these fungi in Brazil.

$B$. dendrobatidis may be able to live saprophytically on keratin in nature if other components of the ecosystem limit the growth of bacteria and phycomycetes (Longcore et al., 1999). Amphibians may maintain B. dendrobatidis in their skin, and when an imbalance in the relationship between fungi and host occurs, these fungi can act as opportunistic microorganisms, potentially causing outbreaks of chytridiomycosis similar to those observed in other countries (Stuart et al., 2004; James et al., 2009; Voyles et al., 2009).

The positivity of $B$. dendrobatidis observed using nested PCR (57\%) was significantly higher than that found
Table 1 - Detection of Batrachochytrium dendrobatidis in healthy freeliving frogs from the Brazilian Atlantic Forest by singleplex and nested PCR.

\begin{tabular}{|c|c|c|c|}
\hline Species & Number & $\begin{array}{l}\text { Singleplex } \\
\text { PCR }\end{array}$ & $\begin{array}{c}\text { Nested } \\
\text { PCR }\end{array}$ \\
\hline Hylodes asper & 6 & Negative & Positive \\
\hline Leptodactylus latrans & 3 & Negative & Positive \\
\hline Scinax alter & 2 & Positive & Positive \\
\hline Adenomera marmorata & 1 & Negative & Positive \\
\hline Dendropsophus minutus & 1 & Positive & Positive \\
\hline Ischnocnema randorum & 1 & Positive & Positive \\
\hline Ischnocnema parva & 1 & Positive & Positive \\
\hline Aplastodiscus arildae & 1 & Negative & Positive \\
\hline Hypsiboas faber & 3 & Positive & Positive \\
\hline Aplastodiscus leucopygius & 1 & Positive & Positive \\
\hline Scinax crospedosfilus & 3 & Negative & Positive \\
\hline Bokermannohyla astartea & 2 & Negative & Positive \\
\hline Hylodes asper & 2 & Positive & Positive \\
\hline Hypsiboas bischoffi & 1 & Negative & Positive \\
\hline Aplastodiscus albosignatus & 1 & Negative & Positive \\
\hline Dendropsophus minutus & 1 & Negative & Positive \\
\hline Hypsiboas bischoffi & 2 & Positive & Positive \\
\hline Hypsiboas polytaenius & 2 & Positive & Positive \\
\hline Hypsiboas polytaenius & 4 & Negative & Positive \\
\hline Physalaemus cuvieri & 1 & Negative & Positive \\
\hline Phyllomedusa burmeisteri & 3 & Negative & Positive \\
\hline Phyllomedusa rohdei & 1 & Negative & Positive \\
\hline Trachycephalus mesophaeus & 2 & Negative & Positive \\
\hline Scinax fuscovarius & 1 & Negative & Positive \\
\hline Hypsiboas semilineatus & 2 & Negative & Positive \\
\hline Trachycephalus mesophaeus & 1 & Positive & Positive \\
\hline Ischnocnema parva & 1 & Negative & Positive \\
\hline Scinax brieni & 1 & Negative & Positive \\
\hline Hylodes phyllodes & 1 & Positive & Positive \\
\hline Ischnocnema guentheri & 1 & Negative & Positive \\
\hline Bokermannhoyla hylax & 1 & Negative & Positive \\
\hline Bokermannohyla circundata & 1 & Positive & Positive \\
\hline Scinax hayii & 3 & Negative & Positive \\
\hline Rhinella ornata & 3 & Negative & Positive \\
\hline Total & & 18 & 61 \\
\hline
\end{tabular}

using singleplex PCR (17\%), suggesting that nested PCR should be the first technique used to detect the fungus between the two tested. These results are in agreement with recent publications that have considered nested and realtime PCR more sensitive than singleplex PCR (Boyle et al., 2004; Garner et al., 2006; Goldberg et al., 2007; Garland et al., 2011).

Nested PCR consists of PCR execution with the product obtained by singleplex PCR, allowing fungus detection 


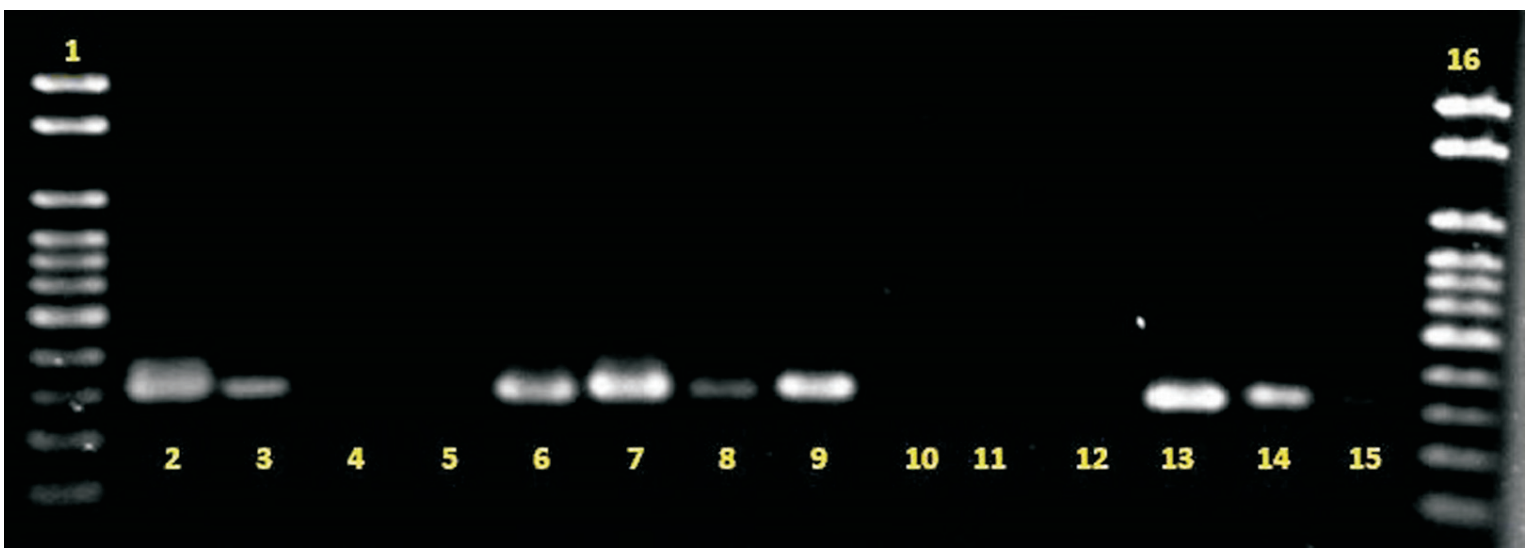

Figure 1 - Electrophoresis on agarose gel. 1 and 16: ladder (100-bp); 2: positive control for $B$. dendrobatidis (300-bp); 3, 6, 7, 8, 9, 13 and 14: positive samples for $B$. dendrobatidis (300-bp); 4, 5, 10, 11, 12 and 15: negative samples for $B$. dendrobatidis.

even when few in number, and nested PCR does not require special equipment. However, nested PCR does not allow quantification (Garner et al., 2006; Goldberg et al., 2007). Real-time PCR has been recommended due to its high sensitivity and ability to quantify of the number of fungi; however, it requires special equipment (Boyle et al., 2004; Garland et al., 2011).

We conclude that $B$. dendrobatidis is very prevalent in the anurans living in the sampled area and that nested PCR can be used as an alternative to epidemiological surveys to detect these fungi on healthy free-living frog populations.

\section{Acknowledgments}

Dr. Allan Pessier - Amphibian Disease Laboratory of San Diego Zoo, California, USA; this research was supported by the grants FAPESP - 2009/52638-3 and CapesPROSUP.

\section{References}

Annis SL, Dastoor FP, Ziel H et al. (2004) A DNA-based assay identifies Batrachochytrium dendrobatidis in amphibians. J Wildl Dis 40:420-428.

Berger L, Speare R, Hyatt A (1999) Diagnosis of chytridiomycosis of amphibians by histological examination. Zoos Print J 15:184-190.

Boyle DG, Boyle DB, Olsen V et al. (2004) Rapid quantitative detection of chytridiomycosis (Batrachochytrium dendrobatidis) in amphibian samples using real-time Taqman PCR assay. Dis Aquat Org 60:141-148.

Carnaval AQ, Toledo LF, Haddad CB et al. (2005) Chytrid fungus infects high-altitude stream-dwelling Hylodes magalhaesi (Leptodactylidae) in the Brazilian Atlantic rainforest. Froglog 70:3.

Carnaval AQ, Puschendorf R, Peixoto OL et al. (2006) Amphibian chytrid fungus broadly distributed in the Brazilian Atlantic rain forest. Ecohealth 1:1-8.

Daszak P, Berger L, Cunningham AA et al. (1999) Emerging infectious diseases and amphibian population declines. Emerg Infect Dis 5:735-748. de Hoog GS, Guarro J, Gené J et al. (2004) Atlas of Clinical Fungi. University of Würzburg, Würzburg. CD-ROM.

de Paula CD, Assis EP, Catão-Dias JL (2010) Chytridiomicosis in captive Dendrobates tinctorius (Anura: Dendrobatidae) in Brazil. International Conference on Diseases of Zoo and Wild Animals, Madrid, Spain, p. 167-168.

Fisher MC, Garner TJ, Walker SF (2009) Global emergence of Batrachochytrium dendrobatidis and amphibian chytridiomycosis in space, time, and host. Annu Rev Microbiol 63:291-310

Frost DR (2013) Amphibian species of the world: an online reference. Version 5.6. Available at: http://research.amnh.org/vz/herpetology/amphibia/. Accessed 15 Aug 2013.

Garland S, Wood J, Skerratt LF (2011) Comparison of sensitivity between real-time detection of a TaqMan assay for Batrachocytrium dendrobatidis and conventional detection. Dis Aquat Org 94:101-105.

Garner TW, Perkins MW, Govindarajulu P et al. (2006) The emerging amphibian Batrachochytrium dendrobatidis globally infects introduced populations of the North American bullfrog, Rana catesbeiana. Biol Lett 2:455-459.

Goldberg TL, Readel AM, Lee MH (2007) Chytrid fungus in frogs from an Equatorial African Mountain Forest in Western Uganda. J Wildl Dis 43:521-524.

Grundler MC, Toledo LF, Parra-Olea G et al. (2012) Interaction between breeding habitat and elevation affects prevalence but not infection intensity of Batrachochytrium dendrobatidis in Brazilian anuran assemblages. Dis Aquat Org 97:173-184.

Hyatt AD, Boyle DG, Olsen V et al. (2007) Diagnostic assays and sampling protocols for the detection of Batrachochytrium dendrobatidis. Dis Aquat Org 73:175 -192.

IUCN-ASG. International Union for Conservation of NatureAmphibian Specialist Group (2013) Available at: http://www.amphibians.org/. Accessed 14 Aug 2013.

James TY, Litvintseva AP, Vilgalys R et al. (2009) Rapid global of the fungal disease chytridiomycosis into declining and healthy amphibian populations. PLoS Path 5:1-12.

Kirshtein JD, Anderson CW, Wood JE et al. (2007) Quantitative PCR detection of Batrachochytrium dendrobatidis DNA from sediments and water. Dis Aquat Org 77:11-15. 
Longcore JE, Pessier AP, Nichols DK (1999) Batrachochytrium dendrobatidis gen. et. sp. nov., a chytrid pathogenic to amphibians. Mycologia 91:219-227.

OIE - World Organisation for Animal Health. Aquatic Animal Health Code. 2006. Infection with Batrachochytrium dendrobatidis. Chapter 8.1. Available at: http://www.oie.int/eng/normes/fcode/fcode2008/en_chapter 8.1.htm. Accessed 15 Aug 2013.

Ramalho AC, de Paula CD, Catão-Dias JL et al. (2013) First Record of Batrachochytrium dendrobatidis in two endemic Cerrado hylids, Bokermannohyla pseudopseudis and $B$. sapiranga, with comments on chytridiomycosis spreading in Brazil. North-West J Zool 9:145-150.

Retallick RR, Miera V, Richards KL et al. (2006) A non-lethal technique for detecting the chytrid fungus Batrachochytrium dendrobatidis on tadpoles. Dis Aquat Org 2006; 72:77-85.

Schloegel LM, Ferreira CM, James TY et al. (2009) The North American bullfrog as a reservoir for the spread of Batrachochytrium dendrobatidis in Brazil. Anim Conserv 13:53-61.

Segalla MV, Caramaschi U, Cruz CG et al. (2012) Brazilian Amphibians-List of species. Sociedade Brasileira de Herpetologia. Available

at: http://www.sbherpetologia.org.br/?page_id $=644$. Accessed 15 Aug 2013.
Siegel S, Castellan N (1988) Nonparametric Statistics for the Behavioral Sciences. McGraw-Hill New York, USA.

Stuart SN, Chanson JS, Cox NA et al. (2004) Status and trends of amphibian declines and extinctions worldwide. Science 306:1783-1786.

Toledo LF, Haddad CB, Carnaval AQ et al. (2006a) A Brazilian anuran (Hylodes magalhaesi: Leptodactylidae) infected by Batrachochytrium dendrobatidis: a conservation concern. Amphib Reptile Conserv 4:17-21.

Toledo LF,Britto FB, Araújo OS et al. (2006b) The occurrence of Batrachochytrium dendrobatidis in Brazil and the inclusion of 17 new cases of infection. South Am J Herpetol 3:185191.

Verdade VK, Carnaval AC, Rodrigues MT et al. (2013) Decline of amphibians in Brazil. In: Heatwole H, Barrio-Amorós C, Wilkinson JW (eds). Amphibian Biology. Status of Decline of Amphibians: Western Hemisphere. Surrey Beatty \& Sons, Chipping Norton, England, 85-127.

Voyles J, Young S, Berger L et al. (2009) Pathogenesis of chytridiomycosis: a cause of catastrophic amphibian declines. Science 326:582-585.

\section{Associate Editor: Odir Antonio Dellagostin}

All the content of the journal, except where otherwise noted, is licensed under a Creative Commons License CC BY-NC. 